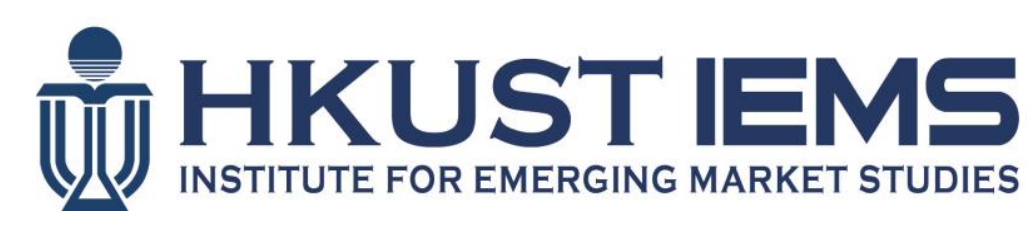

\title{
Does Foreign Bank Entry Affect Monetary Policy Effectiveness?: Exploring the Interest Rate Pass-Through Channel
}

\author{
Sasidaran GOPALAN, Ramkishen S. RAJAN
}

HKUST IEMS Working Paper No. 6

February 2015

HKUST IEMS working papers are distributed for discussion and comment purposes. The views expressed in these papers are those of the authors and do not necessarily represent the views of HKUST IEMS.

More HKUST IEMS working papers are available at: http://iems.ust.hk/WP 


\title{
Does Foreign Bank Entry Affect Monetary Policy Effectiveness?: Exploring the Interest Rate Pass-Through Channel
}

Sasidaran GOPALAN, Ramkishen S. RAJAN

HKUST IEMS Working Paper No. 6

February 2015

\begin{abstract}
This paper explores the impact of foreign bank entry on interest-rate-pass-through for a panel of 57 emerging and developing economies over 1995-2009. The paper tests for possible thresholds in terms of foreign bank presence that differentially impact interest-rate passthrough. The empirical results suggest that there are strong threshold effects in that foreign bank entry tends to enhance interest rate pass-through only in countries with greater degree of foreign bank presence compared to those with limited entry. The paper also finds that when foreign bank entry leads to greater banking concentration, it significantly lowers the extent of interest rate transmission.
\end{abstract}

\section{Author's contact information}

Sasidaran Gopalan

Institute for Emerging Market Studies (IEMS) and Institute for Advanced Study (IAS)

The Hong Kong University of Science and Technology

E: gopalan@ust.hk

Ramkishen S. Rajan

School of Policy, Government and International Affairs (SPGIA)

George Mason University

E: rrajan1@gmu.edu 


\title{
Does Foreign Bank Presence Affect Interest Rate Pass-Through in Emerging and Developing Economies?
}

\author{
Sasidaran Gopalan and Ramkishen S. Rajan1
}

This Version: March 01, 2015

\begin{abstract}
This paper explores the impact of foreign bank presence on interest-rate-pass-through for a panel of 57 emerging and developing economies over 1995-2009. The paper tests for possible thresholds in terms of foreign bank presence that differentially impacts interest-rate transmission. The empirical results suggest that there are strong threshold effects. Countries with significant foreign bank presence witness a strengthening of interest-rate transmission due to foreign bank presence relative to those with a low degree of presence. The paper also finds that when foreign bank presence tends to result in greater banking concentration it significantly lowers the extent of interest-rate transmission.
\end{abstract}

\footnotetext{
${ }^{1}$ Sasidaran Gopalan is Post-Doctoral Research Fellow, Institute for Emerging Market Studies (IEMS) and Institute for Advanced Study (IAS), the Hong Kong University of Science and Technology (HKUST). Email: gopalan@ust.hk
}

Ramkishen S. Rajan is Visiting Professor at Lee Kuan Yew School of Public Policy, National University of Singapore and a Professor at School of Policy, Government and International Affairs at George Mason University. Email: rrajan1@gmu.edu

We would like to thank the participants at the HKUST IEMS Academic Seminar (September 22, 2014) for their valuable suggestions and inputs. 


\section{Introduction}

Since the 1990s, several emerging and developing economies (EMDEs) have opened up their borders to cross-border capital flows. Openness to capital flows has broadly involved a combination of capital account openness to different degrees as well as the internationalization of the financial sector featuring foreign bank entry. Notwithstanding the variations in the degree and scope of their involvement between regions and countries, foreign bank presence has grown significantly across-the-board in EMDEs. For instance, Sub-Saharan Africa saw its foreign bank assets rise from an average of 39 percent in 1996 to close to 60 percent in 2009 and the corresponding share in Europe and Central Asia rose from 17 percent to 60 percent. Latin America also witnessed a remarkable change, with shares growing from 17 percent to 41 percent on average between 1996 and 2009. Compared to the other regions, the degree of foreign bank presence in East Asia and Pacific, South Asia and the Middle East and Northern Africa has been relatively smaller though the shares have been rising in importance as well. While the average share of foreign bank assets doubled between 1996 and 2009 in Middle East and Northern Africa from 7 to 14 percent, East Asia experienced a tripling from 4 to 19 percent in the same period, and South Asia almost doubled from about 8 percent in 1996 to at 15 percent in $2009 .{ }^{2}$

The focus of the literature on foreign bank entry has largely been on how foreign banks have brought greater efficiency gains to the domestic banking system in the host economies (See for instance, Levine, 1996; Clarke et al., 2003; Cull and Martinez Peria, 2010; and Berger, 2007). However, beyond the efficiency-related gains, there is also a growing recognition in the literature about how foreign banks contribute to the development of overall financial and money markets by fostering financial sector depth as well as financial inclusion - the two prime components of financial sector development (See Gopalan, 2015 for a review). ${ }^{3}$ More recently, an emerging literature appears to be more concerned with the role foreign banks play in transmitting different

\footnotetext{
${ }^{2}$ Based on data from Claessens et al. (2008) and World Bank Global Financial Development Database.
} 
kinds of shocks (external and domestic) to the host economies they operate in. This specifically relates to how foreign bank entry and their continued presence affect domestic monetary policy transmission as well as international crisis transmission in EMDEs (See for instance, De Haas and Van Lelyveld, 2006; Detragiache and Gupta, 2006; Galindo et al., 2005 and Choi et al., 2013).

The impact of greater foreign bank presence on domestic monetary policy transmission has become a subject of importance for EMDEs also because several of these economies have gravitated towards more market determined exchange rate regimes. This has in turn resulted in the growing prominence of interest rates as the primary instrument for macroeconomic management in these economies. ${ }^{4}$ While the monetary policy transmission literature has broadly paid more attention to the bank lending channel and the role they play in transmitting shocks to the credit markets through supply-side effects, for several EMDEs with relatively underdeveloped financial markets, the interest rate channel of transmission -- affecting aggregate demand through its impact on the costs of loanable funds -- remains quite important (Mishra and Montiel, 2012). ${ }^{5}$

In this light, an interesting question of relevance to the discussion here is how foreign banks affect interest rate transmission of monetary policy, especially in EMDEs. As the World Bank (2008) notes, there are two conflicting views. First, higher foreign bank participation could strengthen the interest rate transmission indirectly because it contributes to the efficiency and development of the financial sector. On the other hand, the presence of internal capital markets -- one of the distinguishing variables unique to the process of foreign bank lending -- along with the access to

\footnotetext{
${ }^{4}$ There is a general consensus in the literature that there are at least four channels via which monetary policy changes are transmitted to the real economy -- interest rates, exchange rates, asset prices, and the credit channel, with the credit channel further broken down into the bank lending channel and the balance sheet channel. The bank lending channel affects the real economy through the supply of loans while the balance sheet channel operates through the demand for loans. For an overview of the lending channel, see Bernanke and Gertler (1995). In contrast, as noted by Alpanda and Aysun (2012), research on the balance sheet channel has been relatively scarce, mainly because of the difficulty in isolating the independent effects of this channel.

${ }^{5}$ The policy rate also works through its impact on the flow of funds to other assets, such as equities, which causes a rise in the price of the assets stimulating consumption in the economy through the wealth effect and through the impact on investment demand (Islam and Rajan, 2011).
} 
external buffer of funds, allows foreign banks to be less responsive to domestic monetary policy shocks which may reduce the strength of the monetary transmission. ${ }^{6}$ The net impact is a priori unclear and remains an empirical question.

These contrasting views notwithstanding, there are two key relevant factors at work. The first pertains to the structure of the domestic financial system in which foreign banks operate and the second relates to the degree to which they are present in these economies, which in totality could determine the strength of the interest rate pass-through in EMDEs. While the relevant literature seems to focus on estimating both the degree and determinants of interest rate passthrough in many countries, almost no paper to our knowledge explores the impacts of foreign bank presence on interest rate transmission, which will be the focus of this paper.

The remainder of the paper is organized as follows. Section 2 outlines the analytical framework to understand interest rate pass-through and discusses the relationship between foreign bank presence and interest rate transmission by specifying some hypotheses of interest. Section 3 briefly surveys the relevant empirical literature. The empirical model is specified in Section 4. Section 5 summarizes the data sources and undertakes an empirical investigation of the significance of foreign bank presence to the interest rate transmission. Section 6 concludes this paper.

\section{Analytical Framework}

In a seminal paper, Bernanke and Blinder (1988) highlighted the importance of the bank lending channel in transmitting monetary policy shocks. As they argued, when the central bank

\footnotetext{
${ }^{6}$ An active internal capital market is accessible only to the foreign banks which significantly changes the way they respond to different types of shocks in the home as well as host country. The changing nature of banking globalization has altered how banks manage their liquidity as well as how they react in the event of liquidity shocks. As Cetorelli and Goldberg (2009) posit, foreign banks with affiliates abroad can respond to domestic liquidity shocks by activating a cross-border, internal capital market transfer between the head office of the parent bank and its foreign offices, thus reallocating funds on the basis of relative needs which insulates foreign banks from domestic liquidity shocks. This paper will specifically focus on an important channel of domestic monetary policy transmission - the interest rate channel - and how foreign banks impact this transmission channel.
} 
tightens the money supply and draws out banks' reserves which consequently reduce their deposits, the banks are constrained by their inability to perfectly substitute deposits with other liabilities. This eventually leads to a contraction in the supply of credit in the economy, which affects the overall output in the economy (also see Bernanke and Gertler, 1995 and Kashyap and Stein, 1995).

The results of Kashyap and Stein (2000), considered one of the seminal papers in this literature, showed that, in practice, the lending channel works only through the balance sheet of small banks, i.e. size matters. Large banks do not have any difficulty accessing external capital markets and hence any funding shock is absorbed with a potential liability substitution. Campello (2002) shows that even among the smaller banks, only the ones that are stand-alone entities are the worst affected, that is, small banks affiliated with large banks as parts of the same bank holding company are insulated from this problem. This logic can presumably be extended to foreign banks operating in EMDEs too.

While the bank lending channel of monetary transmission focuses on quantity of funds, the related literature notes that the traditional interest rate channel of monetary transmission -- the pass-through from policy rates to retail (lending/deposit) rates -- can occur in two ways. The first direct channel of transmission is known as the monetary policy approach where a change in the monetary policy rate is directly reflected in the long-term lending (and/or deposit) rates. The other indirect channel of transmission -- known as the cost of funds approach (de Bondt, 2005) -- can be broadly decomposed into two stages (Coricelli et al., 2006):

The first stage measures how changes in policy rates are first transmitted to interbank rates - which are the short-term money market rates. It is useful to note that since interbank rates usually happen to be the target rates for the monetary policy, the pass-through from the policy to interbank rates has been observed in the literature to usually be complete and instantaneous. An 
incomplete pass-through between policy and interbank rates usually reflects stresses in the money market (Gigineishvili, 2011).

The second stage pass-through occurs through the government bond market as the changes in inter-bank rates are transmitted to other yields of higher maturity through arbitrage and then to the deposit and lending rates. The key for this stage of transmission to work is the existence of a well-developed yield curve by which changes in short-term rates are passed on to long-term rates. The essence of the two-stage pass-through is that the spread between policy and lending rates depends on the spread between policy and inter-bank rates, spread between inter-bank and government bond rates and finally spread between government bond and lending rates (Illes and Lombardi, 2013). This underlines the importance of structure of the financial markets for a smooth and efficient transmission process (Mishra and Montiel, 2012).

However, the two-stage pass-through may not work effectively for some countries, particularly the EMDEs. When economies have relatively underdeveloped financial and bond markets, the yield curve may not be fully developed, i.e. changes in short-term market rates do not get transmitted to the long-term market rates. In such circumstances, the direct pass-through from the policy rate to the lending and deposit rates would prove to be much more effective (Sander and Kleimer, 2004). This is especially true for a government dominated banking sector where the banking system is susceptible to moral suasion from the central bank (Gigineishvili, 2011).

Why do we expect pass-through to vary based on the degree of foreign bank presence, i.e. is there a reason to believe that there are threshold levels of foreign bank presence for the passthrough to be effective and complete? At the one end of the spectrum, when there is a high degree of government control of the domestic banking system, implying very limited competition, 'moral suasion' could ensure a high pass-through from policy rates to lending rates through the direct channel as governments have full control over the banking system. 
At the other end of the spectrum, an economy characterized by a very high degree of competition with significant foreign bank presence may experience greater banking efficiency and financial sector development that might indirectly strengthen the pass-through. ${ }^{7}$ As the World Bank (2008) notes, "Foreign banks have supported the development of local financial markets in several developing countries, particularly in local securities and derivatives markets by investing considerable capital and expertise. Foreign banks participate as primary dealers in some government bond markets and as pension fund managers and swap dealers in other markets." This occurs primarily through the development and integration of the government and corporate bond markets which will help in the formation of a well-developed and stable yield curve, thereby facilitating the pass-through.

What we are hypothesizing in this paper is that the impact of foreign bank presence on interest rate transmission is not a linear relationship. Foreign banks can strengthen the transmission through financial sector development. But there are threshold effects that one must factor into account. For countries in the intermediate stages of liberalization, for instance, their financial sector is characterized by weak competition which may not be sufficient to contribute to financial market development. However, the process of liberalization would imply a gradual reduction in the power of moral suasion by the government to influence the pass-through. A combination of these factors would result in weakening the transmission of interest rates from the interbank market to the lending or deposit rates. Thus, while greater competition in the banking sector in general could possibly contribute to a tighter pass-through between policy rates and lending rates, there needs to be a certain threshold in terms of foreign bank presence in order for

\footnotetext{
${ }^{7} \mathrm{~A}$ caveat is in order. The environment could be fiercely competitive, with extremely efficient domestic banks as well which may result in foreign banks taking on niche markets that might translate into low asset shares. Alternatively, markets could be far from being competitive but the dominant banks just happen to be from other countries. While admittedly, greater competition in itself need not necessarily imply greater degree of foreign bank presence as competition can also be enhanced through private domestic banks, foreign banks contribute to the enhanced functioning of the money market in addition to transferring technology and best practices which is likely to strengthen the pass-through.
} 
foreign banks to strengthen the interest rate transmission. In other words, at lower levels of foreign bank presence, the second stage pass-through is likely to be weak due to insufficient impact in terms of financial sector development.

That said, from a policy perspective, it is also important to note that if greater foreign bank presence tends to result in higher levels of banking concentration the positive effect on interest rate transmission could be negated. Higher levels of banking concentration would merely imply that the ownership patterns of the banking industry have changed from being a government run monopoly to an oligopolistic-type market structure dominated by a few foreign banks. Such a market structure may lead to weakening the interest rate transmission as foreign banks could refrain from passing on changes in interbank rates to lending/deposit rates. Changes in the policy rates may change the inter-bank rates and the commercial banks might just benefit from the reduction in policy rate but keep their lending rates fixed. So the degree of market power these banks might possess might weaken the transmission.

Hence there is a good reason to suspect a non-linear relationship between foreign bank presence and interest rate transmission. In other words, there are different threshold levels of foreign bank presence associated with different degrees of interest rate pass-through.

\section{Selected Empirical Literature}

There are two sets of related literatures that are relevant for our purposes. The first pertains to a small set of studies that examine the impact of foreign banks on monetary policy transmission which have largely focused on the bank lending channel. The second set of papers, even more limited in number, relates to the determinants of interest rate transmission. While there are two disparate strands of literature, there are no studies that examine the impact of foreign bank presence on interest rate pass-through in a systematic manner, which we attempt to do in this paper. 
From the literature on bank lending channel of monetary transmission, the question that is of interest to us is whether banks with different characteristics - not just size but also ownership respond in a heterogeneous way to monetary policy shocks. Given that foreign banks are equipped with different tools and abilities to shield themselves from monetary policy shocks, how do they impact the monetary transmission through the bank lending channel? While there is a voluminous literature on the bank lending channel in general, there are only a handful of studies that examine the role of foreign banks specifically.

In an analysis of 1,565 banks in 20 Asian and Latin American countries during 1989-2001, Arena et al. (2006) compare the response of the volume of loans, deposits, and bank-specific interest rates on loans and deposits, to various measures of monetary conditions, across domestic and foreign banks. They also look for systematic differences in the behavior of domestic and foreign banks during periods of financial distress and normal times and conclude that there is weak evidence to prove the existence of supply-side effects in credit markets and suggest that foreign bank entry in EMDEs did not contribute to instability in credit markets.

Along similar lines, Jeon and $\mathrm{Wu}$ (2014) examine the impact of increased foreign bank penetration on the monetary policy transmission mechanism in emerging Asian economies during the period from 2000 to 2009 , with a specific focus on the recent global financial crisis. They find on the whole that an increase in foreign bank penetration weakened the effectiveness of the monetary policy transmission mechanism in the host emerging Asian countries during the crisis period.

In a related paper, Wu et al. (2011) study the existence of a bank lending channel in emerging markets, by comparing responses of domestic and foreign banks to host country monetary shocks. Using a sample of more than 1200 banks spread across emerging economies in Eastern and Central Europe, Latin America and Asia over the period 1996 - 2003, they find evidence that foreign banks are less responsive to domestic monetary policy shocks and that they adjust their loan and deposit growth rates less than their domestic counterparts. 
While a limited set of papers that exist in the literature have dealt with only how foreign banks affect the bank lending channel of monetary policy transmission, there are virtually no studies that explicitly test for the impact of foreign banks on direct interest-rate pass through from policy rates to lending rates. However, as already noted earlier, there is a growing literature that seeks to explain the heterogeneity of interest rate pass-through in various countries by examining the significance of various determinants of the strength of interest rate transmission.

Scanning the existing literature on the possible determinants of interest rate pass-through across EMDEs particularly, Gigineishvili (2011) studies 70 countries across all levels of development for the period 2006-09 and observes that a variety of macroeconomic, institutional and regulatory as well as financial structure related factors appear to be significant. In one of the early influential papers on this subject of determinants of interest-rate pass through, for a sample of 31 developed as well as emerging economies for the period 1980-93, Cottarelli and Kourelis (1994) find that a higher inflationary environment, capital mobility, and money market development proxied by volatility of money market rates or by the size of the market for short-term securities result in a stronger interest rate transmission. These variables have emerged important and statistically significant determinants of interest rate transmission in other studies such as Mojon (2000) and Sander and Kleimeir (2004) as well, who undertake similar analysis for a variety of European countries. Sander and Kleimeir (2004) for instance, investigate the transmission of monetary policy onto retail bank interest rates in eight Central and Eastern European countries (CEECs) that joined the European Union in 2004, focusing on the period from 1993 to 2003 and find that market concentration, bank health, foreign bank participation and monetary policy regime are important determinants of interest-rate pass-through.

In a study to assess the importance of financial market developments in influencing the interest rate pass-through, Singh et al. (2008) estimate differences in the nature of interest rate pass-through between 10 developed industrial countries and developing Asian countries between 
1987 and 2006 and compare the estimates with various measures of financial market developments. They find that financial market developments in general lead to stronger interest rate pass-through in terms of both higher immediate and long-run pass-through and also facilitate faster speed of adjustments. ${ }^{8}$

The studies on this subject have unanimously found that banking sector competition strengthens the interest rate transmission in the domestic economy. However, it is interesting to note that the proxies used to measure banking sector competition range from concentration of banking sector to a measure of private ownership of banks (Cottarelli and Kourelis, 1994; Sorensen and Werner, 2006) to an index capturing the degree of banking deregulation in Europe (Mojon, 2000) and have been consistent in their finding that greater banking sector competition tends to improve interest rate pass-through domestically. To our knowledge, the only paper to have used a measure of foreign bank presence -- proxied by the number of foreign banks as a percentage of total number of banks in the economy -- is Sander and Kleimeir (2004), who find a negative and significant relationship with interest-rate pass through. While this seemingly counter-intuitive result could have been driven by the use of the number of foreign banks as opposed to their assets share (which has been acknowledged as a better proxy for foreign bank penetration in the literature), it could also suggest the likely existence of thresholds, a conjecture we attempt to test in this paper. ${ }^{9}$

\footnotetext{
${ }^{8}$ There is a wide variety of banking sector specific variables that are used in various studies which have also been reported to be significant determinants of interest rate pass-through. For instance while improvement in credit risk as captured by loan loss provisioning and portfolio diversification proxied by share of noninterest income to total income appear to strengthen the interest rate transmission, a negative relationship has been found with variables such as banks' excess liquidity, rigidity of bank funding costs as captured by share of deposits in total liabilities, and interest rate risk measured by maturity mismatches (Sorensen and Warner, 2006) and high operating costs captured by personnel costs to gross income (Mojon, 2000).

${ }^{9}$ Other regulatory and institutional variables such as central bank independence appear to possess significant explanatory power for interest rate transmission with a higher degree of independence positively affecting the pass-through (Gigineishvili, 2011).
} 
Overall, the literature seems to be largely silent on the impact of foreign bank presence on interest rate pass-through. None of the studies have tested if foreign bank presence is a plausible determinant of interest rate transmission, something that we propose to do in this paper.

\section{Empirical Model}

As pointed out earlier, interbank rates usually happen to be the target rates for the monetary policy and the pass-through from the policy to interbank rates has been observed in the literature to be usually complete and instantaneous. Hence, our starting point will be to examine the pass-through between the interbank rates and lending rates for our panel of EMDEs.

Our basic estimating equation is given as follows:

$$
L R_{i t}=\delta_{i}+\beta_{1} M M R_{i t}+\beta_{2} f b_{i t}+\beta_{3} f b_{i t} * M M R_{i t}+\beta_{4} Z_{i t}+\beta_{5} Z_{i t} * M M R_{i t}+\mu_{t}+\varepsilon_{i t}
$$

where $L R_{i t}$ is (retail) lending rate and $M M R_{i t}$ is the short-term money market rate and $\beta_{1}$ is the pass-through coefficient, with $\beta$ equaling 1 implying a complete or perfect pass-through and less than 1 signaling an incomplete pass through. We augment this basic pass-through relationship with a proxy for foreign bank presence to test our key conjectures about the influence of foreign bank presence on interest rate pass-through. $f b_{i t}$ measures the share of foreign bank assets in the total domestic banking system in country $i$ at time $t$ and its influence on lending rates is captured by its interaction with money market rates. $\delta_{i}$ is the country fixed effect and $\mu_{t}$ is the time fixed effect.

Before we proceed further, three caveats about quantifying foreign bank presence are in order. First, it is also worth emphasizing the distinction between foreign bank entry and foreign bank presence and its impact on interest-rate transmission. Since we do not have data capturing entry (flow), we will be interested in testing whether the presence of foreign banks (stock) in EMDEs has an effect on effectiveness of a specific channel of monetary policy transmission. 
Second, the literature generally uses foreign bank assets as a share of GDP as the most significant proxy of foreign bank presence, dealing only with those foreign banks that have a "right of establishment" in host countries. While it is true that a holistic measure capturing the importance of foreign banks would involve their cross-border flows as well, it changes the scope of the question and paper. So we confine our focus to examining the impact of foreign bank presence, as measured by their right of establishment. It is also useful to reiterate that the only other related proxy for which we have panel data on a consistent basis available at an annual frequency (as compiled in databases such as the Global Financial Development Database of the World Bank), is the number of foreign banks present in these countries. As is evident, the number of foreign banks is a poor proxy to capture foreign bank presence as the numbers could be affected by consolidations and domestic restructurings among local banks. Therefore, a preferable yardstick of the extent of foreign bank presence in a country is to look at the percentage share of their assets in the domestic banking system, which is what we have used in the paper.

Third there may be concerns about potential endogeneity of foreign bank presence in EMDEs, wherein foreign banks could self-select into already financially well-developed markets. From the perspective of devising a proper identification strategy for our empirics, it is worth emphasizing that several EMDEs gave an impetus for foreign banks to enter their countries by relaxing regulatory restrictions after they underwent a financial crisis (many Asian countries post 1997, for instance) (Gopalan and Rajan, 2010). This in many ways implies a clear exogenous shock in the form of crisis that paved the way for greater entry of foreign banks, affecting the banking structure in a particular country. This, in addition to the use of a fixed effects model, should minimize potential endogeneity concerns and omitted variable bias in our empirics to a reasonable degree although they cannot be ruled out altogether.

We control for a set of macroeconomic and financial sector determinants captured by the vector $\boldsymbol{Z}_{i t}$ and their influence on lending rates through its interaction with the money market rates. 
The choice of these controls variables are based on the available literature on determinants of interest rate pass-through. Specifically, following Sander and Kleimeir (2004) and Gigineishvili (2011), the key macroeconomic determinants we use in our baseline specification are growth, inflation and exchange rate regimes. We augment this specification with financial sector variables that reflect financial sector deepening captured by private credit as a share of GDP and an index of banking concentration given by the Lerner index. We discuss below the priors that we expect to see in our empirics.

\section{$\boldsymbol{Z}_{i t}=\{G D P$ Per Capita, Inflation, Exchange Rate Regime, Credit - to - GDP ratio, Banking Concentration\}}

Growth: Since periods of faster growth allows banks greater flexibility to transmit changes in the policy rate to the lending rates, we include changes in Gross Domestic Product (GDP) per capita as one of our controls.

Inflation: Considering that higher inflation rates could drive banks to adjust their lending rates more in order to safeguard their profit margins, which in turn could imply greater passthrough, we control for prevailing inflation rates. In addition, the uncertainty associated with a high inflation environment could lead banks to pass on the risks to the consumers in order to insulate themselves from potential losses. We use the average change in Consumer Price Index (CPI) for each country over the respective year as a regressor.

Exchange Rate Regimes: One of the other macroeconomic determinants of interest rate transmission relates to the exchange rate regime. A greater degree of exchange rate flexibility is associated with a higher degree of interest rate transmission as it generally enables countries to send credible policy signals to markets that their policy rates have been set with the primary purpose of managing interest rates in their countries. This would ensure that policy rate changes are perceived as credible signals of the policy stance of the central bank. 
As pointed out earlier, apart from macro variables, the literature also suggests that there are a variety of financial sector variables that could influence the degree of interest rate passthrough. However, most of the bank-specific variables could not be used in our estimation owing to lack of consistent data for the sample employed in this study. We use a measure of financial depth as proxied by private credit as a share of GDP and an indicator of banking concentration given by the Lerner index, as defined below.

Private Credit-to-GDP: This measures the financial resources provided to the private sector by domestic money banks as a share of GDP. This variable is also the most commonly used indicator reflecting the extent of financial sector depth in an economy. We expect to see a positive relationship between greater financial sector deepening and interest rate pass-through, as financial sector deepening would lead to greater availability of alternative sources of finance that would in turn lead to increased competition among the financial institutions and improved passthrough to the lending rates.

Lerner Index: It measures market power in the banking industry by comparing output pricing and the marginal costs (markup). An increase in the Lerner index is associated with a decline in bank competition. We are interested in examining if the extent of interest rate transmission decreases when greater foreign bank presence results in greater concentration.

The second part of our estimation strategy is an attempt to explicitly capture the potential nonlinear effects of foreign bank entry on interest rate pass-through. To that end we augment our baseline specification by introducing a quadratic term of foreign bank presence as shown in equation (2).

$L R_{i t}=\delta_{i}+\beta_{1} M M R_{i t}+\beta_{2} f b_{i t}+\beta_{3} f b_{i t} * M M R_{i t}+\beta_{4} f b_{i t}{ }^{2}+\beta_{5} f b_{i t}{ }^{2} * M M R_{i t}+\beta_{6} \boldsymbol{Z}_{i t}+\beta_{7} \boldsymbol{Z}_{i t} * M M R_{i t}+\mu_{t}+\varepsilon_{i t}$ 
$f b_{i t}{ }^{2}$ is our quadratic version of foreign bank variable accounting for the non-linear effects and the interaction term capturing its influence on lending rate. Based on the foregoing discussion, controlling for possible non-linearities of the degree of foreign bank presence we expect $\beta_{3}$ to be positive and significant. Conditional on $\beta_{3}$ being significant, our empirical strategy will involve testing for the influence of foreign bank presence at different threshold levels on the degree of interest rate pass-through. This will involve slicing the panel of EMDEs into sub-samples on the basis of specified exogenous thresholds of foreign bank presence.

We use a linear panel fixed-effects model to estimate equation (1). The rationale behind using fixed effects estimation is that we are able to control for unobserved country-specific fixed characteristics that might affect interest rate pass-through. In addition, our fixed-effects estimates will remain robust only if the potential source of endogeneity arises from the correlation between the time-invariant component of the error term and the regressor of interest. Hence we estimate equation (1) using a fixed-effects panel data model, incorporating country and time fixed effects.

This said, we also ran a Hausman test to decide between fixed effects and random effects estimation. The results suggest that the assumption of absence of any correlation between the time invariant error term and the regressors is not unreasonable and hence favours the use of a generalized least squares (GLS) random effects specification for our panel regressions. However, taking into account the critique in the literature about the limited powers of the Hausman test (Beck, 2001; Cameron 2007) and the potential endogeneity concerns that could be present in estimating our model, we use fixed effects estimation as the preferred methodology throughout the paper and provide random effects results as robustness checks.

\section{Data and Empirical Results}

Data sources are summarized in Annex Table A2. All the macroeconomic controls estimated enter the regression as a differenced logarithmic series. The empirics are performed on a panel dataset of 57 emerging and developing economies (EMDEs), spanning all regions of the world, 
covering the period from 1995 to 2009 (depending on data availability for each economy) (See Annex Table A1). The choice of the countries were random and were dictated by the availability of consistent data on interest rates (money market rates and lending rates) as well as foreign bank assets for the time period concerned. We were left with 57 EMDEs for our empirical estimation as listed in Annex Table A1.

\subsection{Baseline Results}

We start with our baseline model as given by equation (1) that estimates the interest rate pass-through controlling for a set of macroeconomic factors. As the results summarized in Table 1 (Column 1) show, the direct pass-through coefficient turns out to be highly significant with the size of the pass-through from money market rates to lending rates approximately 1 reflecting complete pass-through. However, the key interaction term of interest involving foreign banks and the money market rates -- which allows us to test the impact of foreign bank presence on pass-through-appears to be insignificant. With the exception of the interaction between changes in inflation rate and money market rates, none of the other macroeconomic variables turn out to have a statistically significant impact on pass-through. Even the change in inflation rate appears to be significant only at the 10 percent level and it carries a negative sign, contrary to what we expect from the priors. Column (2) adds financial sector depth to the baseline in column (1). The results do no change from our baseline. The foreign bank variable still remains insignificant.10

\section{[Table 1 about here]}

Among the various reasons as to why the baseline results have not produced significant results could be a misspecification of the model particularly arising from the failure to account for non-linearities in equation (1). We also cross-checked with a visual examination of Kernel density plots, quintile-normal plots and probability normal distribution plots of residuals for the full

\footnotetext{
${ }^{10}$ Another financial sector variable (Lerner Index) to capture the extent of banking concentration was also used but it did not turn out to be significant either.
} 
sample and they suggest possible nonlinearities which could reflect problems of misspecification of the model. Consequently we re-run our baseline model along with a quadratic term of foreign bank presence and its interaction with the money market rates as given in equation (2).

Column (3) in Table 1 provides these results. As is evident, the pass-through coefficient continues to be closer to 1 implying full pass-through like before. In addition to the significance of the money market rates, the interaction terms of both the quadratic term of foreign bank assets as well as its linear counterpart turn out to be statistically significant at the 5 percent level though the economic significance (given by the magnitude of the coefficients) is marginal. This appears to be robust to the inclusion and exclusion of banking credit to private sector (given in column 4). This seems to suggest that there is some non-linear effect of foreign bank presence indicating a likely threshold effect in terms of its implications on interest rate transmission that needs to be explored in further detail.

In Tables 2 and 3, we cross-check the results of our fixed effects estimates with random effects GLS and Maximum Likelihood Estimation (MLE) estimators as robustness. As is apparent, the results are broadly consistent with that of fixed effects. Note that a MLE estimator is expected to capture non-normally distributed error terms better than a GLS estimator. A MLE method in a random effects setup is an iterative approach to fitting data to an underlying relationship. In the case of linear relationships where the error term is normally distributed, OLS estimates are in fact maximum likelihood estimators. But in more complex functions when errors are non-normally distributed, MLEs are required to produce the best estimates. As we can observe, the results in Table 3 are actually stronger in terms of statistical significance of the key interaction terms. We continue to see close to full interest rate pass-through in our baseline estimation and we find the interaction term between foreign bank presence and money market rates to be highly statistically significant at the 1 percent level when we control for quadratic foreign bank presence (as given in 
column 3). This variable continues to remain significant consistently to the inclusion of financial, temporal and regional controls (columns 4 and 5).

\section{[Tables 2 and 3 about here]}

\subsection{Do Foreign Bank Thresholds Matter?}

The results of our baseline estimation discussed above suggest that there is a possible nonlinearity in terms of foreign bank presence. To that end the focus of this section will be to empirically test for threshold effects of foreign bank presence on interest rate pass-through. In an effort to identify the significance of different thresholds, in this section we slice our data sample and re-estimate our baseline equation. As noted earlier, a visual inspection through Kernel density plots of residuals for the full sample also suggest that a sample-splitting is appropriate to deal with possible nonlinearities in the dataset. We slice the data into two categories - high thresholds and low thresholds - with the basis of thresholds being 35 percent of foreign bank assets (as a share of domestic assets) which is the mean of foreign bank assets in our entire sample. ${ }^{11}$ So we slice the sample into two groups -- with countries with foreign bank assets more than 35 percent of the domestic assets, and those with less than 35 percent $^{12}$-- and rerun our baseline equation (1).

The results of the high threshold sample using fixed effects are given in Table 4. The results using random effects MLE for the same sample are in Table 5. Following the high threshold sample results we present the fixed effect estimates for the low threshold sample in Table 6. The random effects MLE results are presented in Table 7.

\footnotetext{
11 The median is close to 30 percent and so using the median instead of the mean produces similar results.

12 We understand that taking the average shares for every country over the sample period could be misleading if the variation within each country is disproportionate over time. However an examination of the within standard deviation of foreign bank assets for the sample reveal no such disproportionately large discrete jumps that would raise concerns. Annex Table A3 reports the summary statistics. Furthermore, as a robustness check we split the sample based on time with different break points and do not find anything significant that would fundamentally challenge our results generated from sample-splitting based on the mean.
} 
Referring to Table 4, we are specifically interested in the direction, magnitude and statistical significance of $\beta_{1}, \beta_{2}$ and $\beta_{3}$ from equation (1) -- the pass-through coefficient, the direct impact of foreign bank presence on lending rates and the interaction term between foreign bank presence and money market rates. As is evident, the results of the high threshold sample are consistent with our priors stated earlier about foreign bank presence, while for the low threshold sample the coefficients carry the right signs though are either weakly statistically significant or insignificant.

Taking a closer look at Table 4, the high threshold sample produces interesting results for the variables of interest. As column (1) illustrates, we can find that pass-through from policy rate to lending rate is more than complete with $\beta_{1}>1$ and is highly statistically significant. Further, we observe that an increase in foreign bank assets is associated with a reduction in lending rates (capturing the direct effects) though the coefficient is not statistically significant. Finally, we can see that the impact of foreign bank presence on pass-through captured by its interaction term with money market rates carries the right sign and is statistically significant as well. Further, changes in GDP growth appear to be positive and statistically significant and increases pass-through.

\section{[Table 4 about here]}

Based on our discussion of priors earlier in the paper we also examine the relationship between banking concentration (Lerner index) and foreign bank presence on interest rate passthrough. If countries with a significant degree of foreign bank presence also appear to have greater concentration in their banking industry, how does the interest rate transmission get affected? Column (2) in Table 3 produces the results. Interestingly, adding a measure of banking concentration to the baseline reduces pass-through, although this decline is not very severe. While we need to interpret this result with caution, at the minimum we can say that when changes in market conduct lead to greater banking concentration (lower banking competition), we observe a 
reduction in interest rate pass-through. ${ }^{13}$ The pass-through coefficient drops by approximately 13 percentage points, with the direct effect of banking concentration on pass-through negative and marginally statistically significant. ${ }^{14}$ Column (3) presents the output of the same regression without year fixed effects, and we find similar results.

Table 5 presents the MLE results for our high threshold sample, with the inclusion of regional and temporal controls and we find broadly consistent results with our baseline fixed effects estimates including the results for banking concentration. An important implication of these results is that if foreign bank presence leads to greater banking concentration it lowers the interest rate transmission in EMDEs, especially if the level of foreign bank presence in the country is above the mean threshold.

\section{[Table 5 about here]}

We estimate a model similar to the one above for the low threshold sample of countries, with the threshold being defined as countries with average foreign bank assets less than 35 percent. As column (1) in Table 6 clearly shows, the pass-through coefficient is incomplete and we do not find foreign bank presence to be significant in influencing the pass-through. The direct impact of foreign bank presence on pass-through should be to increase the lending rate, which is consistent with our priors, though the variable is statistically insignificant. Inclusion of a concentration measure increases the pass-through coefficient. This may allude to the possibility that pass-through is strengthened in such countries with low degrees of foreign bank presence, as greater degree of State-ownership in banking system, results in high interest rate pass-through through moral suasion. This could also imply that these results are suggestive of a weak direct pass-through as foreign banks strengthen the interest rate transmission only indirectly through financial sector

${ }^{13}$ We do not include our financial depth indicator in this regression owing to the general endogeneity concerns highlighted in the foreign bank literature between foreign bank presence and financial sector depth.

${ }^{14} \mathrm{~A}$ triple interaction term between foreign bank entry, banking concentration and money market rates included in estimating the model (not shown) for the high threshold sample of countries carries a negative sign in line with our argument, though remains statistically insignificant. 
development (in countries where they are limited in presence). These results are largely unaffected when we use random effects MLE as the estimating procedure.

\section{[Tables 6 and 7 about here]}

\subsection{Robustness Checks for Thresholds}

The empirical findings reported in the previous section were based on a sample splitting that was done on the basis of the mean of foreign bank asset shares as the identified thresholds. It is important to verify if the results that we have found so far remain consistent and robust to alternative thresholds. Since we observe that the distribution of foreign bank asset shares is skewed, we undertake some robustness checks to ensure consistency of results. To that end we splice the aggregate sample based on countries with greater than 50 percent foreign bank shares and those with less than 50 percent, instead of the 35 percent mean threshold. So we split the aggregate sample into two and re-run our regressions for the specific set of countries that fall on either side of the 50 percent threshold.

Based on our priors it is useful to note that we are more interested in verifying if the highthreshold sample is robust because concentration tends to be more of an issue only in countries with significant foreign bank presence. Accordingly we decompose the high threshold sub-sample originally defined on the basis of the mean and sub-divide it further. Based again on visual Kernel density plots we group countries with foreign bank asset shares less than 35 percent in one group, those between 35 and 65 percent in another and the rest with asset shares above 65 percent as the third group. This also helps us isolate the effects of the outliers in the sample in terms of the countries that have extremely high degree of foreign bank presence.

A summary of these two cases as robustness checks is presented in Table 8 . Recall here that the empirical results reported so far were based on slicing the sample into high and low thresholds using mean foreign bank assets share (35 percent) as the threshold. The key coefficients of interest 
were $\beta_{1}, \beta_{2}$ and $\beta_{3}$ from our baseline equation (1) which pertain to the pass-through coefficient, the direct effect of foreign bank assets on lending rate, and the interaction term between foreign bank presence and policy rate. This baseline was subsequently augmented with a banking concentration measure. As the results in Table 4 showed, for the high threshold sample all the coefficients of interest are significant in both the baseline specification and the augmented baseline with banking concentration. For the low threshold sample however we found that only $\beta_{1}$ and $\beta_{3}$ to be significant in the baseline. None of the coefficients of interest (includes the coefficient of concentration) were significant in the augmented baseline for the low threshold sample.

\section{[Table 8 about here]}

So what we are looking for in the robustness tests are similar results in terms of statistical significance and whether the coefficients are consistent across the different checks for the high threshold sample of countries. The results given in Table 8 show two important points: One, the behavior of coefficients of interest pertaining to the high threshold sample is consistent and robust across different benchmarks. Specifically, the coefficients of all concerned variables carry the expected signs and are statistically significant when we split the sample into half with 50 percent being the threshold. Then, focusing more on the high-threshold sample, we check if there is a subclustering that emerges. ${ }^{15}$ Accordingly, in our second case where we split the high-threshold sample, we find that our results are consistent only for countries with average foreign bank assets within the 35 to 65 percent range and not for the extreme case of those above 65 percent. This suggests that the effect of banking concentration is negligible when there is extremely high presence or low presence of foreign banks. Two, the coefficients continue to underperform in terms

\footnotetext{
15 We also move the threshold to 60 percent instead of 50 percent, i.e. countries above 60 percent grouped as the high threshold sample and those with less than 60 percent as the other and find that the results are broadly consistent with what we find in the 50 percent case. Results are available from the authors on request.
} 
of statistical significance for all the lower-threshold cases though they follow our priors in terms of signs. ${ }^{16}$

Table 9 summarizes the economic significance of our results by showing the magnitude of the foreign bank presence on interest rate transmission under different thresholds, computed from (1). Specifically, we find that in the high threshold sample, the interest rate pass-through increases from 0.75 to 1.22 due to the effect of foreign bank presence. For the sample of countries with average foreign bank assets ranging between 35 and 65 percent, the pass-through increases from 0.81 to 1.25 . In all the low threshold cases, we find that the pass-through is complete though there is no statistically significant impact that foreign bank presence produces. This result conforms to our priors as well because the complete interest rate pass-through occurs directly via the monetary policy channel through moral suasion. Clearly the results are suggestive of a threshold effect where foreign banks boost interest rate transmission in high threshold countries and remain insignificant in the low threshold countries.

\section{[Table 9 about here]}

Overall, the key point is that the results are broadly in favor of our original benchmark case of sample splitting based on the mean of foreign bank assets in the full sample. Further, the robustness checks take us a step further by identifying a sub-cluster within the high-threshold case where countries within the 35 to 65 percent range experience the impacts of banking concentration on interest rate transmission relatively greater than the other categories.

\section{Conclusion}

This paper has explored the impact of foreign bank presence on interest rate pass-through for a panel of 57 emerging and developing economies over the period 1995-2009. The paper has

\footnotetext{
${ }^{16}$ We also perform this exercise for the low threshold sample by clustering those countries that have foreign bank asset shares less than 17 percent and those between 17 and 35 percent as another category but did not find the results to be significant, i.e. the model continues to produce insignificant results for all low-threshold categories. Results are available from the authors on request.
} 
undertaken an empirical investigation of the significance of foreign bank presence to the interest rate transmission with a specific objective of testing for possible identifiable thresholds in terms foreign bank presence that differentially impact pass-through. The empirical results suggest that there are strong threshold effects in terms of foreign bank presence and its impact on the strength of interest rate transmission. We find that foreign bank presence tends to reduce lending rates and enhance interest-rate pass-through in countries that have a relatively high degree of foreign bank presence compared to those with limited presence. We find only weak evidence for foreign banks increasing the lending rates and consequently weakening the interest rate transmission in low threshold economies. The high and low thresholds in the analysis were defined on the basis of the means of foreign bank assets. The results appear to be robust to alternative thresholds as well.

While greater foreign bank presence could contribute to a tighter pass-through between policy rates and lending rates, an important point to underline from a policy perspective is that this relationship could be confounded if higher foreign bank presence results in higher levels of banking concentration. Higher levels of banking concentration would merely imply a change in the ownership pattern of the banking industry from a State-owned monopoly to a private sector oligopoly dominated by foreign banks which in turn might weaken the interest rate transmission.

To that end, this paper formally tested this relationship between banking concentration and foreign bank presence on interest rate pass-through for the high threshold sample and found that the results are in line with the priors, i.e. when foreign bank presence leads to greater banking concentration, it significantly lowers the interest rate transmission. The fact that we find a reduction in the interest rate pass-through coefficient when controlling for concentration reiterates our hypothesis that higher foreign bank presence may not necessarily be beneficial in terms of enhanced pass-through if it is followed by higher banking concentration in the country. This result also has significant policy implications for EMDEs which are in the process of liberalizing their banking sectors and opening them up to foreign competition as it underlines the 
fact that the degree of banking sector competition matters as much as a generalized increase in competition. Finally, we find that within the high-threshold sample the results are consistent only for countries for a sub-cluster of countries with average foreign bank assets within the 35 to 65 percent range and not for the extreme case of those above 65 percent. This appears to suggest that the effect of banking concentration is negligible when there is extremely high presence or low presence of foreign banks. 


\section{References}

Alpanda, S., and U. Aysun. 2012. "Global Banking and the Balance Sheet Channel of Monetary Transmission.” International Journal of Central Banking, 8 (3): 141-75.

Arena, M., C. Reinhart and F. Vazquez. 2006. "The Lending Channel in Emerging Economies: Are Foreign Banks Different"?, National Bureau of Economic Research Working Paper No.12340, Cambridge, USA.

Berger, A.N. 2007. "International Comparisons of Banking Efficiency." Financial Markets, Institutions \& Instruments, 16 (3): 119-144.

Bernanke, B.S., and A.S. Blinder. 1988. "Credit, Money, and Aggregate Demand." National Bureau of Economic Research Working Paper No.2534, Cambridge, USA.

Bernanke, B.S., and M.Gertler. 1995. "Inside the Black Box: The Credit Channel of Monetary Policy Transmission," National Bureau of Economic Research Working Paper No. 5146, Cambridge, USA.

Campello, M., 2002. "Internal Capital Markets in Financial Conglomerates: Evidence from Small Bank Responses to Monetary Policy". Journal of Finance, 57 (6): 2773-2805.

Cetorelli, N., and L. S. Goldberg. 2009. "Globalized Banks: Lending to Emerging Markets in the Crisis.” Federal Reserve Bank of New York Staff Reports No. 377, New York, USA.

Choi, M.J., E. Gutierrez, M.S. Martinez Peria. 2013. "Dissecting Foreign Bank Lending Behavior During the 2008-09 Crisis.” World Bank Discussion Paper 6674, October.

Claessens, S., N. Van Horen, T. Gurcanlar, and J. Mercado. 2008. "Foreign Bank Presence in Developing Countries 1995-2006: Data and Trends." Mimeo.

Clarke, G., R. Cull, M. S. M. Peria, and S. M. Sanchez. 2003. "Foreign Bank Entry: Experience, Implications for Developing Economies, and Agenda for Further Research." The World Bank Research Observer 18 (1): 25-59.

Coricelli, F., B. Egert, and R. Macdonald. 2006. Monetary Transmission in Central and Eastern Europe: Gliding on a Wind of Change. ENB Working Paper Focus 1/06.

Cottarelli, C. and A. Kourelis. 1994. Financial Structure, Bank Lending Rates and the Transmission Mechanism of Monetary Policy. IMF Staff Papers, 41 (4): 587-623.

Cull, R., and M.S. Martinez Peria. 2010. "Foreign Bank Participation in Developing Countries: What Do We Know About the Drivers and Consequences of This Phenomenon?" World Bank Policy Research Working Paper No.5398.

De Bondt, G. 2005, "Interest Rate Pass-Through: Empirical Results for the Euro Area." German Economic Review 6: 37-78.

De Haas, R., and I. Van Lelyveld. 2006. "Foreign Banks and Credit Stability in Central and Eastern Europe: A Panel Data Analysis.” Journal of Banking \& Finance, 30: 1927-1952.

Detragiache, E., and P. Gupta. 2006. "Foreign Banks in Emerging Market Crises: Evidence from Malaysia." Journal of Financial Stability, 2: 217-242. 
Galindo, A., A. Micco, and A. Powell. 2005. "Loyal Lenders or Fickle Financiers: Foreign Banks in Latin America,” Inter-American Development Bank Working Paper No. 529.

Gigineishvili, N. 2011. "Determinants of Interest Rate Pass-Through: Do Macroeconomic Conditions and Financial Market Structure Matter?” IMF Working Paper WP/11/176.

Gopalan, S. 2015. "Financial Liberalisation and Foreign Bank Entry in Emerging and Developing Economies: What Does the Literature Tell Us?," Journal of International Commerce, Economics and Policy, Forthcoming.

Gopalan, S., and R.S. Rajan. 2010. "Financial Sector De-Regulation in Emerging Asia: Focus on Foreign Bank Entry," The Journal of World Investment and Trade, February 2010, 11(1):91-108.

Illes, A. and M. Lombardi. 2013. "Interest Rate Pass-through since the Financial Crisis." BIS Quarterly Review, September.

Islam, S.M. and R.S. Rajan. 2011."Bank Lending Channel of Monetary Transmission Policy: India and the Global Financial Crisis", International Journal of Economics and Business Research, 3 (5): 557575.

Jeon, B.N. and J. Wu. 2014. "The Role of Foreign Banks In Monetary Policy Transmission: Evidence From Asia During The Crisis Of 2008-9", HKIMR Working Paper No.01/2014, January.

Kashyap, A.K., and J.C. Stein. 1995. "The Impact of Monetary Policy on Bank Balance Sheets." In Carnegie-Rochester Conference Series on Public Policy, 42:151-195.

Kashyap, A.K. and J.C. Stein. 2000. "What do a Million Observations on Banks Say About The Transmission of Monetary Policy?,” American Economic Review, 90(3): 407-428.

Levine, R. 1996. "Foreign Banks, Financial Development, and Economic Growth." International Financial Markets: Harmonization Versus Competition, 7: 224-254.

Mishkin, F.S. 1996. "The Channels of Monetary Transmission: Lessons for Monetary Policy," National Bureau of Economic Research Working Paper No.5464, Cambridge, USA.

Mishra, P. and P. Montiel. 2012. "How Effective Is Monetary Transmission in Low-Income Countries? A Survey of the Empirical Evidence." IMF Working Paper No.12/143.

Mojon, B. 2000. "Financial Structure and the Interest Rate Channel of ECB Monetary Policy", ECB Working Paper No. 40.

Sander, H. and S. Kleimeier. 2004. "Interest Rate Pass-Through in an Enlarged Europe: The Role of Banking Market Structure for Monetary Policy Transmission in Transition Countries", Maastricht Research School of Economics of Technology and Organization, Research Memoranda, No. 45.

Singh, S., A. Razi, N. Endut and H. Ramlee. 2008. "Impact of Financial Market Developments on the Monetary Transmission Mechanism," BIS Paper 39e, April.

Sorensen, C.K. and T. Werner. 2006. "Bank Interest Rate Pass-Through In The Euro Area: A Cross Country Comparison,” European Central Bank Working Paper Series No.580, January.

World Bank .2008. Global Development Finance: The Role of International Banking. World Bank. 
Wu, J., B. N. Jeon and A. Luca. 2011. "Foreign Bank Penetration and the Lending Channel in Emerging Economies: Evidence from Bank-Level Panel Data," Journal of International Money and Finance, 30(6): 1128-56. 
Table 1: Impact of Foreign Bank Presence on IRPT - Full Sample (Fixed Effects)

\begin{tabular}{|c|c|c|c|c|}
\hline & $(1)$ & $(2)$ & (3) & $(4)$ \\
\hline Dep Var: Lending Rate (\%) & Baseline & (1) with Fin & Quad FB & (3) with Fin \\
\hline \multirow[t]{2}{*}{ Money Market Rate (\%) } & $1.003^{* * *}$ & $0.968^{* * *}$ & $0.840^{* *}$ & $0.817^{* *}$ \\
\hline & $(0.273)$ & $(0.285)$ & $(0.366)$ & $(0.365)$ \\
\hline \multirow{2}{*}{ Foreign Bank Assets (\%) } & 0.0146 & 0.0217 & -0.123 & -0.119 \\
\hline & $(0.0374)$ & $(0.0411)$ & $(0.102)$ & $(0.152)$ \\
\hline \multirow[t]{2}{*}{$\Delta$ Ln Inflation Rate } & 1.329 & 1.551 & 1.128 & 1.405 \\
\hline & $(1.195)$ & $(1.371)$ & $(1.229)$ & $(1.341)$ \\
\hline \multirow[t]{2}{*}{$\Delta$ Ln GDPPC Growth } & 12.70 & 18.89 & 11.65 & 14.19 \\
\hline & $(20.37)$ & $(24.42)$ & $(18.36)$ & $(20.03)$ \\
\hline \multirow{2}{*}{ Exchange Rate Regime } & -1.498 & -1.545 & -1.505 & -1.539 \\
\hline & $(1.284)$ & $(1.254)$ & $(1.369)$ & $(1.288)$ \\
\hline \multirow[t]{2}{*}{ Private Credit to GDP } & & -0.0529 & & -0.0676 \\
\hline & & $(0.0452)$ & & $(0.0512)$ \\
\hline \multirow[t]{2}{*}{ Foreign Bank Assets Squared } & & & 0.00145 & 0.00152 \\
\hline & & & $(0.00100)$ & $(0.00141)$ \\
\hline \multicolumn{5}{|l|}{ MMR Interacting with: } \\
\hline \multirow[t]{2}{*}{ Foreign Bank Assets (\%) } & 0.00107 & $3.93 e-05$ & $0.0137^{* *}$ & $0.0134^{*}$ \\
\hline & $(0.00300)$ & $(0.00354)$ & $(0.00644)$ & $(0.00769)$ \\
\hline \multirow[t]{2}{*}{$\Delta$ Ln Inflation Rate } & $-0.312^{*}$ & $-0.334^{*}$ & $-0.291^{*}$ & $-0.312^{*}$ \\
\hline & $(0.167)$ & $(0.183)$ & $(0.170)$ & $(0.178)$ \\
\hline \multirow[t]{2}{*}{$\Delta$ Ln GDPPC Growth } & -0.989 & -0.989 & -0.933 & -0.563 \\
\hline & $(1.261)$ & $(1.395)$ & $(1.344)$ & $(1.141)$ \\
\hline \multirow[t]{2}{*}{ Exchange Rate Regime } & 0.0677 & 0.0699 & 0.0509 & 0.0640 \\
\hline & $(0.116)$ & $(0.113)$ & $(0.121)$ & $(0.118)$ \\
\hline \multirow[t]{2}{*}{ Private Credit to GDP } & & 0.00393 & & 0.00588 \\
\hline & & $(0.00354)$ & & $(0.00462)$ \\
\hline \multirow[t]{2}{*}{ Foreign Bank Assets Squared } & & & $-0.000146^{* *}$ & $-0.000168^{* *}$ \\
\hline & & & $(7.31 \mathrm{e}-05)$ & $(8.78 \mathrm{e}-05)$ \\
\hline \multirow[t]{2}{*}{ Constant } & $10.02^{* *}$ & $10.77^{* *}$ & $12.20^{* * *}$ & $12.82^{* * *}$ \\
\hline & $(4.466)$ & $(4.851)$ & $(4.007)$ & $(4.720)$ \\
\hline Observations & 524 & 515 & 524 & 515 \\
\hline R-squared & 0.719 & 0.722 & 0.710 & 0.728 \\
\hline Number of Countries & 49 & 49 & 49 & 49 \\
\hline Country FE & Yes & Yes & Yes & Yes \\
\hline Year FE & Yes & Yes & Yes & Yes \\
\hline
\end{tabular}

Robust Standard Errors Clustered by Countries in Parentheses

${ }^{* * *} \mathrm{p}<0.01,{ }^{* *} \mathrm{p}<0.05,{ }^{*} \mathrm{p}<0.1$ 
Table 2: Random Effects GLS Estimates - Full Sample

\begin{tabular}{|c|c|c|c|c|c|}
\hline Dep Var: Lending Rate (\%) & $\begin{array}{c}\text { Linear } \\
\text { Baseline } \\
\text { (1) }\end{array}$ & $\begin{array}{c}\text { (1) with } \\
\text { Financial } \\
\text { Variable(s) } \\
\text { (2) }\end{array}$ & $\begin{array}{c}\text { (1) with } \\
\text { Quadratic } \\
\text { Interaction } \\
\text { (3) }\end{array}$ & $\begin{array}{c}\text { (3) with } \\
\text { Financial } \\
\text { Variable(s) } \\
\text { (4) }\end{array}$ & $\begin{array}{c}\text { (3) with Regional and } \\
\text { Temporal Effects } \\
\text { (5) }\end{array}$ \\
\hline Money Market Rate (\%) & $\begin{array}{c}0.9847^{* * *} \\
(0.3026)\end{array}$ & $\begin{array}{c}0.9141^{* * *} \\
(0.3084)\end{array}$ & $\begin{array}{c}0.8925^{* * *} \\
(0.3731)\end{array}$ & $\begin{array}{l}0.7792^{* *} \\
(0.3948)\end{array}$ & $\begin{array}{c}0.8153^{* * *} \\
(0.3705)\end{array}$ \\
\hline Foreign Bank Assets (\%) & $\begin{array}{c}0.0153 \\
(0.0332)\end{array}$ & $\begin{array}{c}0.0157 \\
(0.0329)\end{array}$ & $\begin{array}{c}-0.0418 \\
(0.0952)\end{array}$ & $\begin{array}{c}-0.0502 \\
(0.1089)\end{array}$ & $\begin{array}{c}-0.1184 \\
(0.1149)\end{array}$ \\
\hline$\Delta$ Ln Inflation Rate & $\begin{array}{c}1.2513 \\
(1.2952)\end{array}$ & $\begin{array}{c}1.4551 \\
(1.3870)\end{array}$ & $\begin{array}{c}1.1228 \\
(1.2384)\end{array}$ & $\begin{array}{c}1.2940 \\
(1.3510)\end{array}$ & $\begin{array}{c}1.1438 \\
(1.2544)\end{array}$ \\
\hline$\Delta$ Ln GDPPC Growth & $\begin{array}{c}12.5662 \\
(20.3665)\end{array}$ & $\begin{array}{c}17.6203 \\
(25.4951)\end{array}$ & $\begin{array}{c}9.4602 \\
(17.3801)\end{array}$ & $\begin{array}{c}12.9670 \\
(21.8297)\end{array}$ & $\begin{array}{c}13.6814 \\
(22.8631)\end{array}$ \\
\hline Exchange Rate Regime & $\begin{array}{c}-0.9894 \\
(1.1967)\end{array}$ & $\begin{array}{c}-1.1203 \\
(1.2271)\end{array}$ & $\begin{array}{c}-1.0198 \\
(1.2605)\end{array}$ & $\begin{array}{c}-1.1550 \\
(1.2756)\end{array}$ & -1.1036 \\
\hline Foreign Bank Assets Squared & & & $\begin{array}{c}0.0006 \\
(0.0010)\end{array}$ & $\begin{array}{c}0.0008 \\
(0.0011)\end{array}$ & $\begin{array}{c}0.0014 \\
(0.0010)\end{array}$ \\
\hline Private Credit to GDP & & $\begin{array}{l}-0.0561^{*} \\
(0.0316)\end{array}$ & & $\begin{array}{c}-0.0728^{* *} \\
(0.0323)\end{array}$ & \\
\hline \multicolumn{6}{|l|}{ MMR Interacting with: } \\
\hline Foreign Bank Assets & $\begin{array}{c}0.0018 \\
(0.0029)\end{array}$ & $\begin{array}{c}0.0015 \\
(0.0033)\end{array}$ & $\begin{array}{c}0.0117^{*} \\
(0.0064)\end{array}$ & $\begin{array}{c}0.0137^{*} \\
(0.0074)\end{array}$ & $\begin{array}{l}0.0136^{* *} \\
(0.0064)\end{array}$ \\
\hline$\Delta$ Ln Inflation Rate & $\begin{array}{l}-0.3152 * \\
(0.1795)\end{array}$ & $\begin{array}{l}-0.3288^{*} \\
(0.1839)\end{array}$ & $\begin{array}{l}-0.2939^{*} \\
(0.1699)\end{array}$ & $\begin{array}{l}-0.3077^{*} \\
(0.1781)\end{array}$ & $\begin{array}{l}-0.2923^{*} \\
(0.1713)\end{array}$ \\
\hline$\Delta$ Ln GDPPC Growth & $\begin{array}{c}-1.1776 \\
(1.6606)\end{array}$ & $\begin{array}{c}-1.3330 \\
(1.7966)\end{array}$ & $\begin{array}{c}-0.9067 \\
(1.3777)\end{array}$ & $\begin{array}{c}-0.8883 \\
(1.5122)\end{array}$ & $\begin{array}{c}-1.0730 \\
(1.4367)\end{array}$ \\
\hline Exchange Rate Regime & $\begin{array}{c}0.0486 \\
(0.1126)\end{array}$ & $\begin{array}{c}0.0586 \\
(0.1155)\end{array}$ & $\begin{array}{c}-1.0198 \\
(1.2605)\end{array}$ & $\begin{array}{c}0.0533 \\
(0.1211)\end{array}$ & $\begin{array}{c}0.0562 \\
(0.1240)\end{array}$ \\
\hline Foreign Bank Assets Squared & & & $\begin{array}{l}-0.0001^{*} \\
(0.0001)\end{array}$ & $\begin{array}{c}-0.0001^{*} \\
(.0001)\end{array}$ & $\begin{array}{l}-0.0001^{*} \\
(0.0001)\end{array}$ \\
\hline Private Credit to GDP & & $\begin{array}{c}0.0023 \\
(0.0034)\end{array}$ & & $\begin{array}{c}0.0043 \\
(0.0041)\end{array}$ & \\
\hline \multicolumn{6}{|l|}{$\begin{array}{l}\text { Temporal and Regional } \\
\text { Controls }\end{array}$} \\
\hline Global Financial Crisis & & & & & $\begin{array}{l}-2.3129 \\
(1.8310)\end{array}$ \\
\hline MENA & & & & & $\begin{array}{l}-5.3863 \\
(2.7748)\end{array}$ \\
\hline LAC & & & & & $\begin{array}{c}4.7941 \\
(4.8203)\end{array}$ \\
\hline ECA & & & & & $\begin{array}{l}-2.4561 \\
(3.9267)\end{array}$ \\
\hline Asia & & & & & $\begin{array}{l}-7.4283^{*} \\
(2.3536)\end{array}$ \\
\hline \multicolumn{6}{|l|}{$\begin{array}{l}\text { Foreign Bank Assets } \\
\text { Interacting with: }\end{array}$} \\
\hline Global Financial Crisis & & & & & $\begin{array}{l}0.0509^{*} \\
(0.0305)\end{array}$ \\
\hline MENA & & & & & $\begin{array}{c}0.1024 \\
(0.0955)\end{array}$ \\
\hline LAC & & & & & $\begin{array}{l}-0.0306 \\
(0.0613)\end{array}$ \\
\hline ECA & & & & & $\begin{array}{l}-0.0264 \\
(0.0591)\end{array}$ \\
\hline Asia & & & & & $\begin{array}{c}0.1825 \\
(0.0891)\end{array}$ \\
\hline Constant & 8.49 & 10.64 & 9.34 & 11.91 & 12.07 \\
\hline Overall R-Squared & 0.68 & 0.70 & 0.68 & 0.69 & 0.71 \\
\hline Number of Observations & 524 & 515 & 524 & 515 & 524 \\
\hline Number of Countries & 49 & 49 & 49 & 49 & 49 \\
\hline
\end{tabular}

${ }^{* * *} \mathrm{p}<0.01,{ }^{* *} \mathrm{p}<0.05,{ }^{*} \mathrm{p}<0.1$

Robust Standard Errors Clustered by Countries in Parenthesis 
Table 3: Random Effects MLE Estimates - Full Sample

\begin{tabular}{|c|c|c|c|c|c|}
\hline Dep Var: Lending Rate (\%) & $\begin{array}{c}\text { Linear } \\
\text { Baseline } \\
\text { (1) }\end{array}$ & $\begin{array}{c}\text { (1) with } \\
\text { Financial } \\
\text { Variable(s) } \\
\text { (2) }\end{array}$ & $\begin{array}{c}\text { (1) with } \\
\text { Quadratic } \\
\text { Interaction } \\
\text { (3) }\end{array}$ & $\begin{array}{c}\text { (3) with } \\
\text { Financial } \\
\text { Variable(s) } \\
\text { (4) }\end{array}$ & $\begin{array}{l}\text { (3) with Regiona } \\
\text { and Temporal } \\
\text { Effects } \\
\text { (5) }\end{array}$ \\
\hline Money Market Rate (\%) & $\begin{array}{c}0.9833^{* * *} \\
(0.1498)\end{array}$ & $\begin{array}{c}0.9156^{* * *} \\
(0.1537)\end{array}$ & $\begin{array}{c}0.8876^{* * *} \\
(0.1560)\end{array}$ & $\begin{array}{c}0.7785^{* * *} \\
(0.1607)\end{array}$ & $\begin{array}{c}0.8154^{* * *} \\
(0.1630)\end{array}$ \\
\hline Foreign Bank Assets (\%) & $\begin{array}{c}0.0152 \\
(0.0257)\end{array}$ & $\begin{array}{c}0.0160 \\
(0.0266)\end{array}$ & $\begin{array}{l}-0.0504 \\
(0.0909)\end{array}$ & $\begin{array}{l}-0.0580 \\
(0.0925)\end{array}$ & $\begin{array}{l}-0.1157 \\
(0.1108)\end{array}$ \\
\hline$\Delta$ Ln Inflation Rate & $\begin{array}{l}1.2507^{* *} \\
(0.5653)\end{array}$ & $\begin{array}{l}1.4570^{*} \\
(0.5814)\end{array}$ & $\begin{array}{l}1.1222^{* *} \\
(0.5621)\end{array}$ & $\begin{array}{l}1.2959^{* *} \\
(0.5767)\end{array}$ & $\begin{array}{l}1.1449^{* *} \\
(0.5610)\end{array}$ \\
\hline$\Delta$ Ln GDPPC Growth & $\begin{array}{c}12.7773 \\
(11.0179)\end{array}$ & $\begin{array}{c}18.2264 \\
(12.4808)\end{array}$ & $\begin{array}{c}9.7478 \\
(10.9795)\end{array}$ & $\begin{array}{c}13.5832 \\
(12.4217)\end{array}$ & $\begin{array}{c}13.6196 \\
(11.8968)\end{array}$ \\
\hline Exchange Rate Regime & $\begin{array}{l}-1.0353^{*} \\
(0.5985)\end{array}$ & $\begin{array}{l}-1.1826^{*} \\
(0.6089)\end{array}$ & $\begin{array}{l}-1.0198 \\
(0.5939)\end{array}$ & $\begin{array}{c}-1.2077^{* *} \\
(0.6016)\end{array}$ & $\begin{array}{l}-1.0884^{*} \\
(0.5925)\end{array}$ \\
\hline Foreign Bank Assets Squared & & & $\begin{array}{c}0.0007 \\
(0.0010)\end{array}$ & $\begin{array}{c}0.0009 \\
(0.0009)\end{array}$ & $\begin{array}{c}0.0014 \\
(0.0009)\end{array}$ \\
\hline Private Credit to GDP & & $\begin{array}{l}-0.0549^{*} \\
(0.0327)\end{array}$ & & $\begin{array}{l}-0.0716^{* *} \\
(0.0328)\end{array}$ & \\
\hline \multicolumn{6}{|l|}{ MMR Interacting with: } \\
\hline Foreign Bank Assets & $\begin{array}{c}0.0018 \\
(0.0013)\end{array}$ & $\begin{array}{c}0.0015 \\
(0.0015)\end{array}$ & $\begin{array}{l}0.0119 * * * \\
(0.0042)\end{array}$ & $\begin{array}{c}0.0139^{* * *} \\
(0.0043)\end{array}$ & $\begin{array}{l}0.0136^{* * *} \\
(0.0043)\end{array}$ \\
\hline$\Delta$ Ln Inflation Rate & $\begin{array}{c}-0.3151^{* * *} \\
(0.0341)\end{array}$ & $\begin{array}{c}-0.3284^{* * *} \\
(0.0363)\end{array}$ & $\begin{array}{c}-0.2935^{* * *} \\
(0.0347)\end{array}$ & $\begin{array}{l}-0.3072^{* * *} \\
(0.0365)\end{array}$ & $\begin{array}{c}-0.2925^{* * *} \\
(0.0345)\end{array}$ \\
\hline$\Delta$ Ln GDPPC Growth & $\begin{array}{c}-1.1775^{* *} \\
(0.5606)\end{array}$ & $\begin{array}{c}-1.3331^{* *} \\
(0.5766)\end{array}$ & $\begin{array}{l}-0.9067^{*} \\
(0.5638)\end{array}$ & $\begin{array}{c}-0.8880 \\
(1.5845)\end{array}$ & $\begin{array}{c}-1.0761^{* *} \\
(0.5711)\end{array}$ \\
\hline Exchange Rate Regime & $\begin{array}{c}0.0491 \\
(0.0393)\end{array}$ & $\begin{array}{c}0.0590 \\
(0.0407)\end{array}$ & $\begin{array}{c}0.0455 \\
(0.0390)\end{array}$ & $\begin{array}{c}0.0535 \\
(0.0402)\end{array}$ & $\begin{array}{c}0.0562 \\
(0.0394)\end{array}$ \\
\hline Foreign Bank Assets Squared & & & $\begin{array}{c}-0.0001^{* *} \\
(0.0001)\end{array}$ & $\begin{array}{c}-0.0001^{* *} \\
(0.0001)\end{array}$ & $\begin{array}{c}-0.0001^{* *} \\
(0.0001)\end{array}$ \\
\hline Private Credit to GDP & & $\begin{array}{c}0.0027 \\
(0.0019)\end{array}$ & & $\begin{array}{l}0.0042^{* *} \\
(0.0020)\end{array}$ & \\
\hline \multicolumn{6}{|l|}{$\begin{array}{l}\text { Temporal and Regional } \\
\text { Controls }\end{array}$} \\
\hline Global Financial Crisis & & & & & $\begin{array}{c}-2.3096 \\
(2.0290)\end{array}$ \\
\hline MENA & & & & & $\begin{array}{l}-5.2932 \\
(5.4475)\end{array}$ \\
\hline LAC & & & & & $\begin{array}{c}4.8382 \\
(4.6308)\end{array}$ \\
\hline ECA & & & & & $\begin{array}{l}-2.3743 \\
(4.7215)\end{array}$ \\
\hline Asia & & & & & $\begin{array}{l}-7.3685 \\
(5.0148)\end{array}$ \\
\hline \multicolumn{6}{|l|}{$\begin{array}{l}\text { Foreign Bank Assets } \\
\text { Interacting with: }\end{array}$} \\
\hline Global Financial Crisis & & & & & $\begin{array}{c}0.0509 \\
(0.0347)\end{array}$ \\
\hline MENA & & & & & $\begin{array}{c}0.0993 \\
(0.1503)\end{array}$ \\
\hline LAC & & & & & $\begin{array}{l}-0.0314 \\
(0.0658)\end{array}$ \\
\hline ECA & & & & & $\begin{array}{l}-0.0279 \\
(0.0637)\end{array}$ \\
\hline Asia & & & & & $\begin{array}{c}0.1807 \\
(0.1542)\end{array}$ \\
\hline Constant & 8.62 & 10.74 & 9.61 & 12.10 & 11.96 \\
\hline Number of Observations & 524 & 515 & 524 & 515 & 524 \\
\hline Number of Countries & 49 & 49 & 49 & 49 & 49 \\
\hline
\end{tabular}

${ }^{* * *} \mathrm{p}<0.01,{ }^{* *} \mathrm{p}<0.05,{ }^{*} \mathrm{p}<0.1$

Robust Standard Errors Clustered by Countries in Parenthesis 
Table 4: Impact of Foreign Bank Presence on IRPT - High Threshold Sample (Fixed Effects)

\begin{tabular}{|c|c|c|c|}
\hline & $(1)$ & $(2)$ & $(3)$ \\
\hline Dep Var: Lending Rate (\%) & Baseline & (1) With Concentration & (2) Without Year FE \\
\hline \multirow[t]{2}{*}{ Money Market Rate (\%) } & $1.097^{* * *}$ & $0.873^{* * *}$ & $0.739 * * *$ \\
\hline & $(0.276)$ & $(0.272)$ & $(0.204)$ \\
\hline \multirow[t]{2}{*}{ Foreign Bank Assets (\%) } & -0.0283 & -0.0271 & $-0.0607^{* *}$ \\
\hline & $(0.0214)$ & $(0.0246)$ & $(0.0219)$ \\
\hline \multirow[t]{2}{*}{$\Delta$ Ln Inflation Rate } & $-1.004^{* *}$ & -0.662 & $-0.665^{*}$ \\
\hline & $(0.389)$ & $(0.421)$ & $(0.342)$ \\
\hline \multirow[t]{2}{*}{$\Delta$ Ln GDPPC Growth } & $-27.26^{*}$ & $-37.50 * *$ & $-24.19 *$ \\
\hline & $(14.64)$ & $(15.43)$ & $(13.30)$ \\
\hline \multirow[t]{2}{*}{ Exchange Rate Regime } & -1.257 & -1.529 & -1.728 \\
\hline & $(1.558)$ & $(1.620)$ & $(1.636)$ \\
\hline \multirow[t]{2}{*}{ Banking Concentration } & & 6.043 & 4.879 \\
\hline & & $(10.08)$ & $(6.533)$ \\
\hline \multicolumn{4}{|l|}{ MMR Interacting with: } \\
\hline \multirow[t]{2}{*}{ Foreign Bank Assets (\%) } & $0.00195^{* *}$ & $0.00352^{* * *}$ & $0.00429 * * *$ \\
\hline & $(0.000905)$ & $(0.000588)$ & $(0.000873)$ \\
\hline \multirow[t]{2}{*}{$\Delta$ Ln Inflation Rate } & 0.0276 & 0.0105 & 0.0103 \\
\hline & $(0.0426)$ & $(0.0356)$ & $(0.0350)$ \\
\hline \multirow[t]{2}{*}{$\Delta$ Ln GDPPC Growth } & $2.532^{* * *}$ & $2.600^{*}$ & 2.393 \\
\hline & $(0.812)$ & $(1.439)$ & $(1.430)$ \\
\hline \multirow[t]{2}{*}{ Exchange Rate Regime } & -0.0798 & 0.00924 & 0.0523 \\
\hline & $(0.0793)$ & $(0.0708)$ & $(0.0631)$ \\
\hline \multirow[t]{2}{*}{ Banking Concentration } & & $-0.975^{*}$ & $-0.997^{*}$ \\
\hline & & $(0.680)$ & $(0.621)$ \\
\hline \multirow[t]{2}{*}{ Constant } & $17.91^{* * *}$ & $17.96^{* * *}$ & $17.56^{* * *}$ \\
\hline & $(5.441)$ & $(4.635)$ & $(3.667)$ \\
\hline Observations & 258 & 214 & 214 \\
\hline R-squared & 0.775 & 0.792 & 0.770 \\
\hline Number of Countries & 24 & 20 & 20 \\
\hline Country FE & Yes & Yes & Yes \\
\hline Year FE & Yes & Yes & No \\
\hline
\end{tabular}

Robust Standard Errors Clustered for Countries in Parentheses

$* * * \mathrm{p}<0.01, * * \mathrm{p}<0.05, * \mathrm{p}<0.1$ 
Table 5: Random Effects MLE Estimates - High Threshold Sample

\begin{tabular}{|c|c|c|c|c|}
\hline Dep Var: Lending Rate (\%) & $\begin{array}{l}\text { Linear } \\
\text { Baseline } \\
\text { (1) }\end{array}$ & $\begin{array}{c}\text { (1) with } \\
\text { Banking } \\
\text { Concentration } \\
\text { (2) }\end{array}$ & $\begin{array}{l}\text { (1) with Regional } \\
\text { and Temporal } \\
\text { Effects } \\
\text { (3) }\end{array}$ & $\begin{array}{l}\text { (3) with Banking } \\
\text { Concentration } \\
\text { (4) }\end{array}$ \\
\hline Money Market Rate (\%) & $\begin{array}{l}1.0617 * * * \\
(0.1757)\end{array}$ & $\begin{array}{c}0.7540 * * * \\
(0.1932)\end{array}$ & $\begin{array}{c}\text { 1. } 1515^{* * *} \\
(0.1771)\end{array}$ & $\begin{array}{c}0.8893^{* * *} \\
(0.1878)\end{array}$ \\
\hline Foreign Bank Assets (\%) & $\begin{array}{l}-0.0482^{*} \\
(0.0235) \\
\end{array}$ & $\begin{array}{c}-0.0681^{* * *} \\
(0.0242)\end{array}$ & $\begin{array}{l}-0.0214 \\
(0.0635)\end{array}$ & $\begin{array}{c}-0.0564 \\
(0.0792) \\
\end{array}$ \\
\hline$\Delta$ Ln Inflation Rate & $\begin{array}{l}-1.1197^{* *} \\
(0.5608)\end{array}$ & $\begin{array}{c}-0.5541 \\
(0.5564)\end{array}$ & $\begin{array}{l}-1.4152^{* *} \\
(0.5646)\end{array}$ & $\begin{array}{l}-0.8617 \\
(0.5528)\end{array}$ \\
\hline$\Delta$ Ln GDPPC Growth & $\begin{array}{c}-23.7437^{* *} \\
(10.3255)\end{array}$ & $\begin{array}{c}-23.9472 * * \\
(10.7287)\end{array}$ & $\begin{array}{c}-30.3622^{* * *} \\
(11.2830)\end{array}$ & $\begin{array}{c}-37.6858 * * * \\
(11.8089)\end{array}$ \\
\hline Exchange Rate Regime & $\begin{array}{l}-0.7280 \\
(0.7736)\end{array}$ & $\begin{array}{c}-0.9773 \\
(0.7981)\end{array}$ & $\begin{array}{c}-0.7426 \\
(0.7469)\end{array}$ & $\begin{array}{c}-0.8908 \\
(0.7525)\end{array}$ \\
\hline Banking Concentration & & $\begin{array}{c}3.2666 \\
(6.1018)\end{array}$ & & $\begin{array}{c}4.9429 \\
(5.8277)\end{array}$ \\
\hline \multicolumn{5}{|l|}{ MMR Interacting with: } \\
\hline Foreign Bank Assets & $\begin{array}{c}0.0026^{* * *} \\
(0.0010)\end{array}$ & $\begin{array}{c}0.0046^{* * *} \\
(0.0011)\end{array}$ & $\begin{array}{c}0.0025^{* * *} \\
(0.0010)\end{array}$ & $\begin{array}{c}0.0041 * * * \\
(0.0010)\end{array}$ \\
\hline$\Delta$ Ln Inflation Rate & $\begin{array}{c}0.0279 \\
(0.0311)\end{array}$ & $\begin{array}{c}0.0052 \\
(0.0362)\end{array}$ & $\begin{array}{c}0.0387 \\
(0.0303)\end{array}$ & $\begin{array}{l}0.0162 \\
(.0347)\end{array}$ \\
\hline$\Delta$ Ln GDPPC Growth & $\begin{array}{l}2.6266^{* * *} \\
(0.6548)\end{array}$ & $\begin{array}{l}2.2825^{* * *} \\
(0.7254)\end{array}$ & $\begin{array}{l}2.8555^{* * *} \\
(0.6453)\end{array}$ & $\begin{array}{l}2.7102^{* * *} \\
(0.7025)\end{array}$ \\
\hline Exchange Rate Regime & $\begin{array}{l}-0.07314 \\
(0.0492) \\
\end{array}$ & $\begin{array}{c}0.0381 \\
(0.0524)\end{array}$ & $\begin{array}{c}-0.1001^{* *} \\
(0.0494) \\
\end{array}$ & $\begin{array}{c}0.0019 \\
(0.0509)\end{array}$ \\
\hline Banking Concentration & & $\begin{array}{c}-1.0003^{* * *} \\
(0.3097)\end{array}$ & & $\begin{array}{c}-1.0593^{* * *} \\
(0.2957)\end{array}$ \\
\hline \multicolumn{5}{|l|}{$\begin{array}{l}\text { Temporal and Regional } \\
\text { Controls }\end{array}$} \\
\hline Global Financial Crisis & & & $\begin{array}{c}-15.1972 * * * \\
(4.0339)\end{array}$ & $\begin{array}{c}-13.4997 * * * \\
(4.3029)\end{array}$ \\
\hline MENA & & & $\begin{array}{l}-20.5859 \\
(37.7498) \\
\end{array}$ & $\begin{array}{c}-9.9566 \\
(35.1817)\end{array}$ \\
\hline LAC & & & $\begin{array}{c}6.5275 \\
(6.9060) \\
\end{array}$ & $\begin{array}{c}9.1781 \\
(7.7448) \\
\end{array}$ \\
\hline ECA & & & $\begin{array}{l}-3.9034 \\
(6.5741)\end{array}$ & $\begin{array}{l}-4.6228 \\
(7.3561)\end{array}$ \\
\hline \multicolumn{5}{|l|}{$\begin{array}{l}\text { Foreign Bank Assets } \\
\text { Interacting with: }\end{array}$} \\
\hline Global Financial Crisis & & & $\begin{array}{c}0.1767 * * * \\
(0.0525) \\
\end{array}$ & $\begin{array}{l}0.1297 * * \\
(0.0563)\end{array}$ \\
\hline MENA & & & $\begin{array}{c}0.2128 \\
(0.5835)\end{array}$ & $\begin{array}{c}0.0571 \\
(0.5453)\end{array}$ \\
\hline LAC & & & $\begin{array}{l}-0.0693 \\
(0.0687)\end{array}$ & $\begin{array}{l}-0.0587 \\
(0.0853)\end{array}$ \\
\hline ECA & & & $\begin{array}{l}-0.0077 \\
(0.0673)\end{array}$ & $\begin{array}{c}0.0187 \\
(0.0813) \\
\end{array}$ \\
\hline Constant & 14.01 & 15.81 & 14.85 & 16.40 \\
\hline Number of Observations & 258 & 214 & 258 & 214 \\
\hline Number of Countries & 24 & 20 & 24 & 20 \\
\hline
\end{tabular}

${ }^{* * *}$ Significant at the $1 \%$ level; ${ }^{* *}$ Significant at the $5 \%$ level; ${ }^{*}$ Significant at the $10 \%$ level; Standard Errors in parenthesis 
Table 6: Impact of Foreign Bank Presence on IRPT - Low Threshold Sample (Fixed Effects)

\begin{tabular}{|c|c|c|}
\hline & $(1)$ & $(2)$ \\
\hline Dep Var: Lending Rate (\%) & Baseline & (1) With Concentration \\
\hline \multirow[t]{2}{*}{ Money Market Rate (\%) } & $0.831^{* *}$ & $1.107^{* *}$ \\
\hline & $(0.364)$ & $(0.488)$ \\
\hline \multirow[t]{2}{*}{ Foreign Bank Assets (\%) } & 0.0219 & 0.000365 \\
\hline & $(0.125)$ & $(0.152)$ \\
\hline \multirow[t]{2}{*}{$\Delta$ Ln Inflation Rate } & $4.969 * * *$ & $3.346^{*}$ \\
\hline & $(1.309)$ & $(1.784)$ \\
\hline \multirow[t]{2}{*}{$\Delta$ Ln GDPPC Growth } & $38.68^{*}$ & 17.70 \\
\hline & $(21.55)$ & $(26.40)$ \\
\hline \multirow[t]{2}{*}{ Exchange Rate Regime } & $-1.772^{* * *}$ & -0.291 \\
\hline & $(0.631)$ & $(1.158)$ \\
\hline \multirow[t]{2}{*}{ Banking Concentration } & & -0.0249 \\
\hline & & $(10.47)$ \\
\hline \multicolumn{3}{|l|}{ MMR Interacting with: } \\
\hline \multirow[t]{2}{*}{ Foreign Bank Assets (\%) } & 0.00169 & 0.000960 \\
\hline & $(0.0109)$ & $(0.00918)$ \\
\hline \multirow[t]{2}{*}{$\Delta$ Ln Inflation Rate } & $-0.765^{* * *}$ & $-0.578^{* *}$ \\
\hline & $(0.129)$ & $(0.235)$ \\
\hline \multirow[t]{2}{*}{$\Delta$ Ln GDPPC Growth } & $-3.785^{* * *}$ & $-4.420^{*}$ \\
\hline & $(1.116)$ & $(2.422)$ \\
\hline \multirow[t]{2}{*}{ Exchange Rate Regime } & $0.175^{* * *}$ & -0.0592 \\
\hline & $(0.0332)$ & $(0.191)$ \\
\hline \multirow[t]{2}{*}{ Banking Concentration } & & 0.881 \\
\hline & & $(1.311)$ \\
\hline \multirow[t]{2}{*}{ Constant } & $7.415^{*}$ & $7.650^{* * *}$ \\
\hline & $(4.149)$ & $(2.237)$ \\
\hline Observations & 252 & 222 \\
\hline R-squared & 0.886 & 0.755 \\
\hline Number of Countries & 24 & 20 \\
\hline Country FE & Yes & Yes \\
\hline Year FE & Yes & Yes \\
\hline
\end{tabular}

Robust Standard Errors Clustered for Countries in Parentheses

${ }^{* * *} \mathrm{p}<0.01,{ }^{* *} \mathrm{p}<0.05,{ }^{*} \mathrm{p}<0.1$

Table 7: Random Effects MLE Estimates - Low Threshold Sample

\begin{tabular}{|l|c|c|c|c|}
\hline \multicolumn{1}{|c|}{$\begin{array}{c}\text { Dep Var: Lending Rate } \\
\text { (\%) }\end{array}$} & $\begin{array}{c}\text { Linear } \\
\text { Baseline }\end{array}$ & $\begin{array}{c}\text { (1) with } \\
\text { Banking } \\
\text { Concentration } \\
\text { (2) }\end{array}$ & $\begin{array}{c}\text { (1) with Regional } \\
\text { and Temporal } \\
\text { Effects } \\
\text { (3) }\end{array}$ & $\begin{array}{c}\text { (3) with Banking } \\
\text { Concentration } \\
\text { (4) }\end{array}$ \\
\hline Money Market Rate (\%) & $\mathbf{( 1 )}$ & 0.5994 & $0.5717 * * *$ & 0.5535 \\
& $(0.3148)$ & $(0.5790)$ & $(0.1983)$ & $(0.4464)$ \\
\hline Foreign Bank Assets (\%) & 0.0237 & 0.0601 & 0.0011 & 0.0605 \\
& $(0.0894)$ & $(0.1131)$ & $(0.0847)$ & $(0.1062)$ \\
\hline$\Delta$ Ln Inflation Rate & $4.6361^{* * *}$ & $3.4009 * *$ & $4.7511^{* * *}$ & $3.5099 * * *$ \\
& $(1.3842)$ & $(1.7446)$ & $(0.6576)$ & $(0.6093)$ \\
\hline$\Delta$ Ln GDPPC Growth & $34.4406 *$ & 22.8525 & $31.5944 * *$ & 16.2427 \\
& $(19.0300)$ & $(24.0967)$ & $(15.4745)$ & $(15.5726)$ \\
\hline
\end{tabular}




\begin{tabular}{|c|c|c|c|c|}
\hline Exchange Rate Regime & $\begin{array}{c}-1.6674 * * * \\
(0.5852)\end{array}$ & $\begin{array}{l}-0.9867 \\
(1.2878)\end{array}$ & $\begin{array}{c}-2.0361^{* * *} \\
(0.6128)\end{array}$ & $\begin{array}{l}-1.1420 \\
(0.8106)\end{array}$ \\
\hline Banking Concentration & & $\begin{array}{l}-5.1345 \\
(9.3399)\end{array}$ & & $\begin{array}{c}-6.0872 \\
(7.1890)\end{array}$ \\
\hline \multicolumn{5}{|l|}{ MMR Interacting with: } \\
\hline Foreign Bank Assets & $\begin{array}{l}0.0076^{*} \\
(0.0095)\end{array}$ & $\begin{array}{l}0.0036 \\
(.0089)\end{array}$ & $\begin{array}{l}0.0098^{* *} \\
(0.0106)\end{array}$ & $\begin{array}{c}0.0083 \\
(0.0060)\end{array}$ \\
\hline$\Delta$ Ln Inflation Rate & $\begin{array}{c}-0.7429 * * * \\
(0.1398)\end{array}$ & $\begin{array}{c}-0.5937 * * * \\
(0.2253)\end{array}$ & $\begin{array}{c}-0.7395^{* * *} \\
(0.0451)\end{array}$ & $\begin{array}{c}-0.5906^{* * *} \\
(0.0495)\end{array}$ \\
\hline$\Delta$ Ln GDPPC Growth & $\begin{array}{c}-3.503^{* * *} \\
(1.1162)\end{array}$ & $\begin{array}{l}-3.6664 \\
(2.5400) \\
\end{array}$ & $\begin{array}{c}-3.6234 * * * \\
(0.6761)\end{array}$ & $\begin{array}{c}-3.9785^{* * *} \\
(1.0136) \\
\end{array}$ \\
\hline Exchange Rate Regime & $\begin{array}{l}0.1752 * * * \\
(0.0354)\end{array}$ & $\begin{array}{c}0.0995 \\
(0.2295)\end{array}$ & $\begin{array}{l}0.1868^{* * *} \\
(0.0396)\end{array}$ & $\begin{array}{c}0.0813 \\
(0.1096)\end{array}$ \\
\hline Banking Concentration & & $\begin{array}{c}1.2581 \\
(1.2498)\end{array}$ & & $\begin{array}{c}1.0464 \\
(0.6784)\end{array}$ \\
\hline \multicolumn{5}{|l|}{$\begin{array}{l}\text { Temporal and Regional } \\
\text { Controls }\end{array}$} \\
\hline Global Financial Crisis & & & $\begin{array}{c}1.7606 \\
(2.5337)\end{array}$ & $\begin{array}{c}0.5848 \\
(2.3840)\end{array}$ \\
\hline MENA & & & $\begin{array}{c}-0.3981 \\
(3.9228)\end{array}$ & $\begin{array}{l}-0.0591 \\
(4.2308)\end{array}$ \\
\hline LAC & & & $\begin{array}{c}12.5996^{* * *} \\
(4.0120)\end{array}$ & $\begin{array}{c}19.0932^{* * *} \\
(4.9238)\end{array}$ \\
\hline ECA & & & $\begin{array}{c}8.2577 \\
(4.8814)\end{array}$ & $\begin{array}{l}8.5913^{*} \\
(5.2067)\end{array}$ \\
\hline \multicolumn{5}{|l|}{$\begin{array}{l}\text { Foreign Bank Assets } \\
\text { Interacting with: }\end{array}$} \\
\hline Global Financial Crisis & & & $\begin{array}{l}-0.06424 \\
(0.1077)\end{array}$ & $\begin{array}{l}-0.0856 \\
(0.1164)\end{array}$ \\
\hline MENA & & & $\begin{array}{c}0.1849 \\
(0.2054)\end{array}$ & $\begin{array}{c}0.1403 \\
(0.2001)\end{array}$ \\
\hline LAC & & & $\begin{array}{l}-0.2861^{*} \\
(0.1606)\end{array}$ & $\begin{array}{c}-0.4204^{* * *} \\
(0.1678)\end{array}$ \\
\hline ECA & & & $\begin{array}{l}-0.1423 \\
(0.1307)\end{array}$ & $\begin{array}{l}-0.1664 \\
(0.1395)\end{array}$ \\
\hline Constant & 10.06 & 8.67 & 7.36 & 7.34 \\
\hline Number of Observations & 252 & 222 & 252 & 222 \\
\hline Number of Countries & 24 & 20 & 24 & 20 \\
\hline
\end{tabular}

*** Significant at the $1 \%$ level; ** Significant at the $5 \%$ level; * Significant at the $10 \%$ level.

Standard Errors in parenthesis 
Table 8: Significance of Model under Alternative Thresholds

\begin{tabular}{|c|c|c|c|c|c|}
\hline Thresholds & Model & $\begin{array}{c}\text { Pass-through } \\
\text { coefficient } \\
\left(\beta_{1}\right)\end{array}$ & $\begin{array}{c}\text { Foreign } \\
\text { Bank Asset } \\
\left(\beta_{2}\right)\end{array}$ & $\begin{array}{c}\text { Interaction } \\
\text { FB Asset* } \\
\text { MMR } \\
\left(\beta_{3}\right)\end{array}$ & $\begin{array}{c}\text { Interaction } \\
\text { MMR* } \\
\text { Concentration }\end{array}$ \\
\hline \multicolumn{6}{|l|}{ Case-I: } \\
\hline \multirow{2}{*}{ FBA $>50 \%$} & Baseline (1) & Significant & Significant & Significant & - \\
\hline & $\begin{array}{l}\text { (1) Augmented } \\
\text { with banking } \\
\text { concentration (2) }\end{array}$ & Significant & Significant & Significant & Significant \\
\hline \multirow[t]{2}{*}{ FBA $<50 \%$} & Baseline (1) & Significant & Insignificant & Significant & - \\
\hline & $\begin{array}{l}\text { (1) Augmented } \\
\text { with banking } \\
\text { concentration ( } 2 \text { ) }\end{array}$ & Significant & Insignificant & Insignificant & Insignificant \\
\hline \multicolumn{6}{|l|}{ Case-II: } \\
\hline \multirow{2}{*}{ FBA $<35 \%$} & Baseline (1) & Significant & Insignificant & Insignificant & - \\
\hline & $\begin{array}{l}\text { (1) Augmented } \\
\text { with banking } \\
\text { concentration (2) }\end{array}$ & Significant & Insignificant & Insignificant & Insignificant \\
\hline \multirow[t]{2}{*}{$35<$ FBA $<65 \%$} & Baseline (1) & Significant & Significant & Significant & - \\
\hline & $\begin{array}{l}\text { (1) Augmented } \\
\text { with banking } \\
\text { concentration ( } 2 \text { ) }\end{array}$ & Significant & Significant & Significant & Significant \\
\hline \multirow[t]{2}{*}{ FBA $>65 \%$} & Baseline (1) & Insignificant & Insignificant & Insignificant & - \\
\hline & $\begin{array}{l}\text { (1) Augmented } \\
\text { with banking } \\
\text { concentration (2) }\end{array}$ & Insignificant & Insignificant & Insignificant & Insignificant \\
\hline
\end{tabular}

Table 9: IRPT Coefficients under Various Thresholds

\begin{tabular}{|l|l|l|l|l|l|}
\hline & $\begin{array}{l}\text { High Threshold } \\
(>35 \%)\end{array}$ & $\begin{array}{l}\text { Low Threshold } \\
(<35 \%)\end{array}$ & 0 $<$ FBE $<17 \%$ & $\mathbf{1 7}<$ FBE $<35 \%$ & $35<$ FBE $<65 \%$ \\
\hline IRPT & 0.74 & 1.10 & 1.01 & 1.12 & 0.81 \\
\hline $\begin{array}{l}\text { IRPT } \\
\text { with FBE }\end{array}$ & 1.22 & - & - & - & 1.25 \\
\hline
\end{tabular}


Table A1: Full Sample - List of Countries and Regions

\begin{tabular}{|l|l|}
\hline Region & Country \\
\hline East Asia and Pacific (EAP) & Indonesia, Korea, Malaysia, Philippines, Thailand \\
\hline Europe and Central Asia (ECA) & $\begin{array}{l}\text { Armenia, Bulgaria, Croatia, Czech Republic, Estonia, } \\
\text { Georgia, Kyrgyz Republic, Latvia, Lithuania, Moldova, } \\
\text { Romania, Russia, Serbia, Slovak Republic, Slovenia, } \\
\text { Ukraine. }\end{array}$ \\
\hline Latin America and Caribbean (LAC) & $\begin{array}{l}\text { Antigua, Argentina, Bolivia, Brazil, Chile, Colombia, } \\
\text { Dominican Republic, Guatemala, Jamaica, Mexico, } \\
\text { Panama, Paraguay, Peru, Uruguay, Venezuela }\end{array}$ \\
\hline Middle East and North Africa (MENA) & $\begin{array}{l}\text { Algeria, Bahrain, Jordan, Kuwait, Libya, Morocco and } \\
\text { Oman }\end{array}$ \\
\hline South Asia (SA) & \begin{tabular}{l} 
India, Pakistan and Sri Lanka \\
\hline Sub Saharan Africa (SSA)
\end{tabular} \\
$\begin{array}{l}\text { Madagascar, Mali, Mauritius, Mozambique, Namibia, } \\
\text { Niger, Rwanda, Senegal, South Africa, Togo, } \\
\text { Zimbabwe }\end{array}$ \\
\hline
\end{tabular}

Table A2 - Variable Definitions and Sources

\begin{tabular}{|c|c|c|}
\hline Variable & Definition & Source \\
\hline Lending Rate (\%) & $\begin{array}{l}\text { Lending Rate is the domestic rate at which banks lend to meet } \\
\text { the short- and medium-term financing needs of the private } \\
\text { sector. This rate is for the domestic economy. }\end{array}$ & $\begin{array}{l}\text { IMF International Financial } \\
\text { Statistics }\end{array}$ \\
\hline Money Market Rate (\%) & Short-term money market rates & $\begin{array}{l}\text { IMF International Financial } \\
\text { Statistics }\end{array}$ \\
\hline Foreign Bank Assets (\%) & Share of foreign bank assets in total banking assets & Claessens, et al. (2008) \\
\hline $\begin{array}{l}\text { Inflation (Average CPI: } \\
2005=100 \text { ) }\end{array}$ & $\begin{array}{l}\text { Average Inflation measured by Consumer Price Index in } 2005 \\
\text { prices }\end{array}$ & $\begin{array}{l}\text { Global Financial Development } \\
\text { Database - World Bank }\end{array}$ \\
\hline $\begin{array}{l}\text { GDP Per Capita (Constant } \\
2000 \text { USD) }\end{array}$ & GDP Per Capita measured in 2000 US dollars & $\begin{array}{l}\text { Global Financial Development } \\
\text { Database - World Bank }\end{array}$ \\
\hline Exchange Rate Regime & $\begin{array}{l}1 \text { - no separate legal tender/ pre-announced pegs } \\
2 \text { - crawling pegs narrower than or equal to+ } /-2 \% \\
3 \text {-managed floating } \\
\text { 4-freely floating } \\
\text { 5-freely falling } \\
\text { 6-dual market in which parallel market data is missing }\end{array}$ & $\begin{array}{l}\text { Ilzetzki, Reinhart and Rogoff } \\
\text { (2008) }\end{array}$ \\
\hline Private Credit to GDP (\%) & $\begin{array}{l}\text { The financial resources provided to the private sector by } \\
\text { domestic money banks as a share of GDP. Domestic money banks } \\
\text { comprise commercial banks and other financial institutions that } \\
\text { accept transferable deposits, such as demand deposits. } \\
\text { (International Monetary Fund, International Financial Statistics, } \\
\text { and World Bank GDP estimates) }\end{array}$ & $\begin{array}{l}\text { Global Financial Development } \\
\text { Database - World Bank }\end{array}$ \\
\hline $\begin{array}{l}\text { Banking Concentration } \\
\text { (Lerner Index) }\end{array}$ & $\begin{array}{l}\text { A measure of market power in the banking market. It compares } \\
\text { output pricing and marginal costs (that is, markup). An increase } \\
\text { in the Lerner index indicates a deterioration of the competitive } \\
\text { conduct of financial intermediaries. (Bankscope) }\end{array}$ & $\begin{array}{l}\text { Global Financial Development } \\
\text { Database - World Bank }\end{array}$ \\
\hline Global Financial Crisis & $\begin{array}{l}\text { Dummy for Global Financial Crisis taking the value } 1 \text { for } 2008 \\
\text { and } 2009 .\end{array}$ & Author \\
\hline
\end{tabular}


Table A3: Summary Statistics

\begin{tabular}{|l|c|c|c|c|}
\hline \multicolumn{1}{|c|}{ Variables } & No. of Obs. & No. of Countries & Mean & Within Std. Dev \\
\hline Lending Rate (\%) & 806 & 52 & 22.1 & 29.7 \\
\hline Money Market Rate (\%) & 818 & 57 & 10.8 & 11.8 \\
\hline Foreign Bank Assets (\%) & 783 & 57 & 35.1 & 18.8 \\
\hline Ln GDP Per Capita & 907 & 57 & 3686.1 & 742.5 \\
\hline Exchange Rate Regime & 849 & 57 & 2.6 & 0.8 \\
\hline Ln Inflation & 820 & 57 & 1.7 & 0.9 \\
\hline Private Credit to GDP (\%) & 824 & 57 & 34.7 & 11.6 \\
\hline Banking Concentration & 673 & 46 & 0.2 & .07 \\
\hline
\end{tabular}

